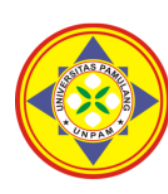

\title{
PENGARUH DISIPLIN KERJA DAN PELATIHAN KERJA TERHADAP KINERJA KARYAWAN PADA HOTEL CITRADREAM BINTARO TANGERANG SELATAN
}

\author{
${ }^{1 *}$ Veritia, ${ }^{2}$ Siti Amalia \\ Universitas Pamulang, Tangerang, Banten, Indonesia \\ *dosen00822@unpam.ac.id
}

\begin{abstract}
Abstrak
Penelitian ini bertujuan untuk mengetahui pengaruh disiplin kerja dan pelatihan kerja terhadap kinerja karyawan Hotel Citradream Bintaro Tangerang Selatan. Metodologi penelitian yang digunakan menggunakan metode Asosiatif. Populasi dalam penelitian ini adalah seluruh karyawan yang bekerja pada Hotel Citradream Bintaro Tangerang Selatan sebanyak 51 orang. Sampel sebanyak 51 responden dengan menggunakan teknik sampling jenuh. Metode analisis data menggunakan uji regresi linier sederhana, regresi linier berganda, koefisien korelasi, koefisien determinasi, uji t parsial dan uji $\mathrm{F}$ simultan. Hasil penelitian menunjukan bahwa: (1) Terdapat pengaruh positif dan signifikan antara disiplin kerja terhadap kinerja karyawan dari nilai $t_{\text {hitung }} 5,946>t_{\text {tabel }} 2,009$ dengan tingkat signifikan $0,000<0,05$. (2) Terdapat pengaruh positif dan signifikan antara pelatihan kerja terhadap kinerja karyawan dari nilai $t_{\text {hitung }} 6,692>t_{\text {tabel }}$ 2,009 dengan tingkat signifikan 0,000<0,05. (3) Secara simultan terdapat pengaruh positif dan signifikan antara disiplin kerja dan pelatihan kerja terhadap kinerja karyawan dari nilai $\mathrm{F}_{\text {hitung }} 38,494>\mathrm{F}_{\text {tabel }} 4,04$ dengan tingkat siginifikan 0,000 < 0,05.
\end{abstract}

Kata Kunci: Pelatihan, Disiplin Kerja, Kinerja Karyawan

\section{Abstract}

This study aims to determine the effect of work discipline and job training on employee performance at Hotel Citradream Bintaro, South Tangerang. The research methodology used is the associative method. The population in this study were all employees who worked at Hotel Citradream Bintaro, South Tangerang, as many as 51 people. A sample of 51 respondents using saturated sampling technique. Methods of data analysis using simple linear regression test, multiple linear regression, correlation coefficient, coefficient of determination, partial $t$ test and simultaneous F test. The results showed that: (1) There is a positive and significant influence between work discipline on employee performance from the tcount of 5,946> ttable 2,009 with a significant level of 0,000 $<0.05$. (2) There is a positive and significant influence between job training on employee performance from the tcount of 6.692> ttable 2.009 with a significant level of $0.000<0.05$. (3) Simultaneously there is a positive and significant influence between work discipline and job training on employee performance from the value of Fcount $38.494>$ Ftable 4.04 with a significant level of $0.000<0.05$.

Keywords: Training, Work Discipline, Employee Performance

\section{PENDAHULUAN}

Sumber daya manusia merupakan salah satu faktor penting sebagai modal manusia dalam suatu organisasi atau perusahaan. Persaingan yang ketat dalam bisnis, membuat berbagai industri harus bekerja keras meningkatkan kinerja perusahaannya. Tidak terkecuali pada industri perhotelan.

Hotel Citradream Bintaro merupakan perusahaan jasa yang bergerak di sektor pariwisata khususnya pada bidang perhotelan. Ketatnya persaingan pada bidang perhotelan, membuat Hotel Citradream Bintaro, selalu ingin memberikan pelayanan yang berkualitas kepada pengunjungnya. Menurut Sulastiyono (2011) Hotel merupakan suatu perusahaan yang dikelola oleh pemiliknya dengan memberikan pelayanan makanan, minuman dan fasilitas kamar untuk tidur kepada orang-orang yang melakukan perjalanan dan mampu membayar dengan jumlah yang wajar sesuai dengan pelayanan 
yang diterima tanpa adanya perjanjian khusus.

Berdasarkan hasil pengamatan yang dilakukan dengan pihak manajemen

Tabel 1. Fenomena Kinerja Karyawan Hotel Citradream Bintaro

\begin{tabular}{|c|l|}
\hline Indikator & \multicolumn{1}{|c|}{ Fakta Rill Kinerja Karyawan } \\
\hline Kualitas kerja & $\begin{array}{l}\text { Pengetahuan karyawan hotel dalam memahami tugas-tugas yang diberikan oleh } \\
\text { atasan, masih kurang baik. Hal tersebut dikarenakan masih adanya keluhan- } \\
\text { keluhan dari pelanggan mengenai pelayanan yang kurang sesuai harapan } \\
\text { pelanggan. }\end{array}$ \\
\hline Kuantitas kerja & $\begin{array}{l}\text { Beberapa karyawan menyelesaikan pekerjaan dengan hasil yang tidak sesuai } \\
\text { dengan target yang telah ditentukan oleh perusahaan sehingga hasil pekerjaan } \\
\text { dinilai kurang maksimal. }\end{array}$ \\
\hline Kerjasama & $\begin{array}{l}\text { Belum terjalinnya kekompakan dari setiap karyawan untuk menyelesaikan } \\
\text { pekerjaan bersama dengan karyawan lain. Karyawan masih mementingkan ego } \\
\text { masing-masing dalam menyelesaikan pekerjaan karena adanya perbedaan } \\
\text { persepsi. }\end{array}$ \\
\hline Tanggung jawab & $\begin{array}{l}\text { Masih ada sebagian karyawan yang tidak mampu menyelesaikan pekerjaan } \\
\text { sesuai dengan waktu yang telah ditentukan. }\end{array}$ \\
\hline Inisiatif & $\begin{array}{l}\text { Insiatif dari karyawan untuk menyelesaikan pekerjaan tanpa menunggu } \\
\text { perintah dari pemimpin, masih kurang. Sehingga karyawan masih terlihat } \\
\text { kurang mandiri dalam menyelesaikan pekerjaan. }\end{array}$ \\
\hline
\end{tabular}

Sumber : Manajemen Hotel Citradream Bintaro (2020)

Tabel 1, menunjukkan bahwa kinerja karyawan masih belum sesuai harapan. Permasalahan kinerja karyawan ini akan berdampak kurang baik bagi perkembangan Hotel Citradream Bintaro, Tangerang Selatan. Bisa saja para pelanggan beralih ke hotel lain yang tentunya memberikan pelayanan yang lebih memuaskan. Seorang karyawan dikatakan memiliki kinerja yang tinggi jika beban kerja yang diberikan tercapai dan jika mengenai kinerja karyawan, ditemukan permasalahan sebagai berikut: realisasi hasil kerja tinggi dari pada yang ditetapkan perusahaan.

Adapun salah satu faktor yang mempengaruhi kinerja karyawan menjadi menurun adalah disiplin kerja. Menurut Hasibuan (2016:193), "kedisiplinan adalah kesadaran dan kesediaan seseorang menaati semua peraturan perusahaan dan norma-norma sosial yang berlaku".

Berikut tabel data absensi karyawan Hotel Citradream Bintaro, Tangerang Selatan selama Periode 2017 - 2019.

Tabel 2. Data Absensi Karyawan Hotel Citradream Bintaro Periode 2017 - 2019

\begin{tabular}{|c|c|c|c|c|c|c|c|c|}
\hline \multirow{2}{*}{ Tahun } & \multirow{2}{*}{$\begin{array}{c}\text { Jumlah } \\
\text { Karyawan }\end{array}$} & \multirow{2}{*}{$\begin{array}{c}\text { Jumlah } \\
\text { HK }\end{array}$} & \multirow{2}{*}{$\begin{array}{c}\text { Total } \\
\text { HK }\end{array}$} & \multicolumn{3}{|c|}{$\begin{array}{c}\text { Alasan Tidak Masuk } \\
\text { Kerja }\end{array}$} & \multirow{2}{*}{ Jumlah } & \multirow{2}{*}{ (\%) } \\
\cline { 5 - 7 } & & & Telat & Izin & Alfa & & \\
\hline 2017 & 53 & 365 & 19.345 & 40 & 10 & 6 & 56 & $15,34 \%$ \\
\hline 2018 & 51 & 365 & 18.615 & 36 & 12 & 5 & 53 & $14,52 \%$ \\
\hline 2019 & 51 & 365 & 18.615 & 72 & 12 & 7 & 91 & $24,93 \%$ \\
\hline \multicolumn{7}{|c|}{ Rata-rata } \\
\hline
\end{tabular}

Sumber: Hotel Citradream Bintaro, 2020

Tabel 2 menunjukkan tingkat ketidakhadiran karyawan mengalami peningkatan setiap tahun. Pada tahun 2017 jumlah karyawan yang tidak hadir sebanyak 56 orang $(15,34 \%)$. Pada tahun 2018 jumlah karyawan yang tidak hadir meningkat menjadi 53 orang $(14,52 \%)$. Pada tahun 2019 jumlah karyawan yang tidak hadir juga mengalami peningkatan menjadi
91 orang (24,93\%). Hal tersebut menunjukan bahwa disiplin kerja karyawan pada Hotel Citradream Bintaro, Tangerang Selatan terkait dengan kehadiran masih rendah dan belum optimal.

Selain disiplin kerja, indikasi lain yang mempengaruhi kinerja karyawan Hotel Citradream Bintaro, Tangerang Selatan adalah pelatihan kerja. Pelatihan 
kerja diberikan kepada karyawan baru maupun karyawan lama. Berikut ini adalah beberapa data kehadiran peserta pelatihan tahun 2019:

Tabel 3. Kehadiran Peserta Pelatihan Tahun 2019

\begin{tabular}{|c|l|l|c|c|c|}
\hline No & \multicolumn{1}{|c|}{ Jabatan } & \multicolumn{1}{|c|}{ Materi Pelatihan } & $\begin{array}{c}\text { Total } \\
\text { Undangan }\end{array}$ & $\begin{array}{c}\text { Total } \\
\text { Peserta }\end{array}$ & Selisih \\
\hline 1 & Accounting & Analisis Laporan Keuangan & 6 & 3 & -3 \\
\hline 2 & Front office & Tata cara penyambutan tamu & 4 & 2 & -2 \\
\hline 3 & FEB Service & Food and beverage department & 8 & 3 & -5 \\
\hline 4 & Security & Tata cara menjaga keamanan hotel & 7 & 4 & -3 \\
\hline 5 & House Keeping & Housekeeping Training management & 15 & 7 & -8 \\
\hline 6 & Kitchen & Manajemen dapur & 7 & 5 & -2 \\
\hline 7 & Enggenering & Engineering Risk Management & 4 & 1 & -3 \\
\hline
\end{tabular}

Sumber : Hotel Citradream Bintaro, 2020.

Tabel 3, menunjukkan jumlah peserta pelatihan yang hadir tidak sesuai dengan jumlah peserta yang diundang. Paling banyak adalah karyawan dengan jabatan House keeping, hampir setengah dari jumlah undangan tidak hadir. Hal ini menunjukkan adanya masalah pada pelatihan kerja di Hotel Citradream Bintaro, Tangerang Selatan.

\section{TINJAUAN PUSTAKA}

\section{Disiplin Kerja}

Hasibuan (2016:193) memberikan definisi, "kedisiplinan adalah kesadaran dan kesediaan seseorang menaati peraturan-peraturan yang ada diperusahaan dan norma-norma sosial yang berlaku". Lalu Mangkunegara (2016:129) menyatakan "Kedisiplinan dapat diartikan sebagai pelaksanaan manajemen untuk memperteguh pedoman-pedoman organisasi". Sedangkan Sutrisno (2016:87) menyatakan bahwa "disiplin mempunyai dua pengertian. Pertama, melibatkan belajar atau mencetak perilaku dengan menerapkan imbalan atau hukuman. Kedua, disiplin hanya bertalian dengan tindakan hukuman terhadap perilaku kesalahan".

2. Pelatihan Kerja

Dessler

mengemukakan bahwa "Pelatihan merupakan proses mengajarkan pegawai baru atau yang ada sekarang, keterampilan dasar yang mereka butuhkan untuk menjalankan pekerjaan mereka. Pelatihan merupakan salah satu usaha dalam meningkatkan mutu sumber daya manusia dalam dunia kerja. Pegawai baik yang baru atau pun yang sudah bekerja perlu mengikuti pelatihan". Gomes (2016:197) mendefinisikan pelatihan adalah setiap usaha untuk memperbaiki prestasi kerja pada suatu pekerjaan tertentu yang sedang menjadi tanggung jawabnya. Menurut Widodo (2015:82), pelatihan merupakan serangkaian aktivitas individu dalam meningkatkan keahlian dan pengetahuan secara sistematis sehingga mampu memiliki kinerja yang profesional di bidangnya.

3. Kinerja Karyawan

Menurut Mangkunegara (2016:67), "kinerja adalah hasil kerja secara kualitas dan kuantitas yang dicapai oleh seorang pegawai dalam melaksanakan tugasnya sesuai dengan tanggung jawab yang diberikan kepadanya". Edison (2016:190), mendefinisikan "Kinerja adalah hasil dari suatu proses yang mengacu dan diukur selama periode waktu tertentu berdasarkan ketentuan atau kesepakatan yang telah ditetapkan sebelumnya". Sedangkan menurut Hasibuan (2016:138), "kinerja karyawan suatu hasil yang dicapai oleh seseorang dalam melaksanakan tugas-tugas yang dibebankan kepadanya". 


\section{METODE}

Penelitian ini dilaksanakan di Hotel Citradream Bintaro yang berlokasi di Jalan Bintaro Utama III Sektor 3A, Pd. Karya, Kec. Pd. Aren, Kota Tangerang Selatan, Banten 15225. Waktu Penelitian ini dilaksanakan selama 7 (tujuh) bulan yang dimulai dari bulan Juni - Desember 2020.

Populasi dalam kajian ini adalah semua karyawan yang bekerja pada Hotel Citradream Bintaro, Tangerang Selatan sebanyak 51 orang karyawan. Tehnik pengumpulan sampel, memakai metode sampling jenuh, sejumlah 51 karyawan. Teknik pengumpulan data menggunakan uji instrumen data, uji prasyarat data dan uji statistic. Jenis penelitian ini adalah kuantitatif, dengan menggunakan metode asosiatif.

\section{HASIL DAN PEMBAHASAN}

1.Pembahasan Hasil Penelitian

Berdasarkan hasil penelitian yang telah dijelaskan sebelumnya menunjukkan bahwa terdapat pengaruh positif dan signifikan baik secara parsial maupun simultan disiplin kerja dan pelatihan kerja terhadap kinerja karyawan. Berikut ini dipaparkan penjelasan atas jawaban dari hipotesis penelitian.

a. Pengaruh Disiplin Kerja (X1) Terhadap Kinerja Karyawan $(Y)$

Berdasarkan hasil penelitian pada variabel disiplin kerja (X1) memiliki pengaruh pada kinerja karyawan $(\mathrm{Y})$ Hotel Citradream Bintaro, Tangerang Selatan. Pengaruh disiplin kerja terhadap kinerja karyawan dapat dijelaskan oleh beberapa faktor dari jawaban responden. Misalnya saja, indicator disiplin kerja pada pernyataan selalu hadir tepat waktu pada saat jam kerja menjadi skor paling rendah yakni 3.04. Bisa dikatakan banyak karyawan yang masih belum bisa hadir tepat waktu, sehingga kedisiplinan dalam kerja sangat diperlukan.

Hasil penelitian ini, diperoleh nilai persamaan regresi $\mathrm{Y}=27,950+0,357 \mathrm{X}_{1}$ koefisien korelasi sebesar 0.647 artinya kedua variabel mempunyai tingkat pengaruh yang kuat. Uji hipotesis diperoleh nilai $\mathrm{t}$ hitung $>\mathrm{t}$ tabel atau $(5,946>2,009)$, hal ini diperkuat dengan probability significancy $0.000<0.05$, dengan demikian $\mathrm{H} 0$ ditolak dan $\mathrm{H} 1$ diterima artinya terdapat pengaruh yang signifikan secara parsial antara disiplin kerja terhadap Kinerja karyawan pada Hotel Citradream Bintaro, Tangerang Selatan. Hasil pengujian sejalan dengan hasil penelitian terdahulu yaitu Siskawati (2017), Azwar \& Abrian (2015) serta Hajrina \& Wijayanti (2016).

b. Pengaruh Pelatihan Kerja (X2) Terhadap Kinerja Karyawan (Y)

Berdasarkan hasil uji hipotesis pertama, ditemukan bahwa Pelatihan Kerja (X2) memiliki pengaruh terhadap Kinerja (Y) Karyawan Hotel Citradream Bintaro., Tangerang Selatan. Pengaruh pelatihan kerja dapat dilihat dari indikator instruktur, dimana instruktur harus bekerja secara profesional. Indikator ini menjadi indikator yang paling rendah yaitu 3.10. Hal ini berarti pelatih / instruktur yang professional dalam bidangnya ketika memberikan ilmunya dalam arti kompeten sangat penting dalam proses pemberian pelatihan kerja. Karena menyangkut output dari pelatihan kerja itu sendiri.

Hasil penelitian ini, diperoleh nilai persamaan regresi $\mathrm{Y}=22,613+0,460 \mathrm{X}_{2}$, koefisien korelasi sebesar 0. 691 artinya kedua variabel mempunyai tingkat pengaruh yang kuat. Uji hipotesis diperoleh nilai $\mathrm{t}$ hitung $>\mathrm{t}$ tabel atau $(6,692>2,009)$, hal ini diperkuat dengan probability significancy $0.000<0.05$, dengan demikian $\mathrm{H} 0$ ditolak dan $\mathrm{H} 2$ diterima artinya terdapat pengaruh yang signifikan secara parsial antara Pelatihan Kerja terhadap Kinerja karyawan Hotel Citradream Bintaro, Tangerang Selatan. Hasil pengujian sejalan dengan hasil penelitian terdahulu yaitu Akbari \& Anggela (2020), Tambunan (2021) serta Rahayu \& Ramadhani (2018). 
c. Pengaruh Disiplin Kerja $\left(\mathrm{X}_{1}\right)$ dan Pelatihan Kerja (X2) Secara Simultan Terhadap Kinerja karyawan (Y)

Hasil penelitian ini menunjukkan bahwa Disiplin Kerja (X1) dan Pelatihan Kerja (X2) berpengaruh positif terhadap Kinerja Karyawan (Y). Pengaruh kinerja karyawan dapat dilihat dari indicator kinerja karyawan pada pernyataan hasill kerja sudah melebihi harapan instansi tempat bekerja menjadi indicator paling rendah yaiktu 3.24. Hal ini menunjukkan kuantitas pekerjaan sangat diperlukan dan berpengaruh pada kinerja karyawan. Hasil pengujian ini sejalan dengan hasil penelitian terdahulu.

Indikator dengan diperoleh persamaan regresi $Y=19,358+0,231 X_{1}+0,333 X_{2}$. Nlai koefisien korelasi atau tingkat pengaruh antara variabel bebas dengan variabel terikat diperoleh sebesar 0,785 artinya memiliki memiliki pengaruh yang kuat. Uji hipotesis diperoleh nilai Fhitung $>$ Ftabel atau $(38,494>4,04)$, hal tersebut juga diperkuat dengan probability significancy $0,000<0,05$. Dengan demikian $\mathrm{H} 0$ ditolak dan $\mathrm{H} 3$ diterima. Artinya terdapat pengaruh yang signifikan secara simultan antara disiplin kerja dan pelatihan kerja terhadap Kinerja karyawan Hotel Citradream Bintaro, Tangerang Selatan. Hasil pengujian sejalan dengan hasil penelitian terdahulu yaitu Hartono \& Siagian (2020), Aulia (2018) serta Ayuningtias \& Nainggolan (2019).

\section{PENUTUP}

Simpulan

Berdasarkan uraian pada penjelasan sebelumnya, dan dari hasil analisis serta pembahasan mengenai pengaruh Disiplin Kerja dan Pelatihan Kerja terhadap Kinerja Karyawan Hotel Citradream Bintaro, Tangerang Selatan, maka :

1. Disiplin kerja berpengaruh signifikan secara parsial terhadap Kinerja Karyawan dengan uji hipotesis diperoleh $t$ hitung $>t$ tabel atau $(5.946>2.009)$, hal ini diperkuat dengan probability signifikansi $0,000<0,05$, dengan demikian $\mathrm{H} 0$ ditolak dan $\mathrm{H} 1$ diterima artinya terdapat pengaruh signifikan antara Disiplin Kerja secara parsial terhadap Kinerja Karyawan pada Hotel Citradream Bintaro, Tangerang Selatan.

2. Pelatihan Kerja berpengaruh signifikan secara parsial terhadap Kinerja Karyawan dengan uji hipotesis diperoleh t hitung > t tabel atau $(6.692>2.009)$, hal ini diperkuat dengan probability signifikansi $0,000<0,05$, dengan demikian $\mathrm{H} 0$ ditolak dan $\mathrm{H} 2$ diterima artinya terdapat pengaruh signifikan antara Pelatihan kerja secara parsial terhadap Kinerja Karyawan (Y) pada Hotel Citradream Bintaro, Tangerang Selatan.

3. Disiplin Kerja dan Pelatihan Kerja berpengaruh signifikan secara simultan terhadap Kinerja Karyawan dengan uji hipotesis diperoleh nilai $\mathrm{F}$ hitung $>\mathrm{F}$ tabel atau $(38.494>4.04)$, hal tersebut juga diperkuat dengan probability signifikansi $0,000<0,05$. Dengan demikian $\mathrm{H} 0$ ditolak dan $\mathrm{H} 3$ diterima. Artinya terdapat pengaruh signifikan secara simultan antara Disiplin kerja dan Pelatihan Kerja terhadap Kinerja Karyawan pada Hotel Citradream Bintaro, Tangerang Selatan.

\section{Saran}

Berdasarkan hasil penelitian yang didapatkan maka saran yang dapat sampaikan kepada Hotel Citradream Bintaro, Tangerang Selatan adalah:

1. Variabel Disiplin Kerja, pernyataan paling lemah adalah pada indicator taat terhadap aturan waktu yakni pada pernyataan selalu hadir tepat waktu pada saat jam kerja menjadi skor paling rendah yakni 3.04. Disarankan manajemen hotel lebih ketat dan tegas dalam mengawasi dan mengontrol aturan waktu ini. Dibuat standar operasi prosedur (SOP) yang jelas, dengan pemberian hukuman sesuai pelanggarannya, sehingga memberikan efek jera.

2. Variabel Pelatihan Kerja, pernyataan paling lemah adalah pada indicator 
instruktur, yaitu pernyataan instruktur sudah bekerja professional menjadi skor paling rendah yakni 3.10. Disarankan, manajemen hotel memilih instruktur yang kompeten dan selalu meningkatkan materi-materi pelatihan terbaru.

3. Variable Kinerja Karyawan, pernyataan paling lemah adalah pada indikator kuantitas, yaitu pada pernyataan hasil kerja sudah melebihi harapan instansi tempat bekerja menjadi indikator paling rendah yakni 3.24. Disarankan perlu adanya penguatan kerja tim. Kerja tim diharapkan dapat menghasilkan hasil kerja melebihi target perusahaan. Serta menciptakan budaya kerja yang baik sehingga akan meningkatkan kinerja yang optimal.

\section{DAFTAR PUSTAKA}

Akbari, D., Nurlenawati, N., \& Anggela, F. P. (2020). Pengaruh Pelatihan Terhadap Kinerja Pelaku UMKM Karawang (Kasus Pada Peserta UMKM Juara). Jurnal Mahasiswa Manajemen dan Akuntansi, 1(2).

Aulia, R. (2018). Pengaruh Disiplin Kerja dan Pelatihan Kerja terhadap Kinerja Karyawan pada PT. Trans Fashion Indonesia. Universitas Pamulang. Tangerang Selatan.

Ayuningtias, N., \& Nainggolan, B. M. (2019). Pengaruh Pelatihan Karyawan, Disiplin Kerja dan Motivasi Terhadap Kinerja Karyawan di Blue Sky Pandurata Boutique Hotel Jakarta. STEIN eRepository, 6(1).

Azwar, H., \& Abrian, Y. (2015). Pengaruh Disiplin Kerja Terhadap Kinerja Karyawan di Hotel Grand Inna Muara Padang. E-Journal Home Economic and Tourism, 9(2).

Dessler, G. (2015). Manajemen Sumber Daya Manusia. Jakarta: Salemba Empat.

Edison, E. (2016). Manajemen Sumber Daya Manusia. Bandung: Alfabeta.

Gomes, F. C. (2016). Manajemen Sumber Daya Manusia. Jakarta: Andi Offset.

Hajrina, R. A., Mariam, I., \& Wijiyanti, M. (2016). Pengaruh Disiplin Kerja
Terhadap Kinerja Karyawan Bagian Marketing Pada Hotel Millennium Sirih, Jakarta. Epigram, 13(2).

Hartono, T., \& Siagian, M. (2020). Pengaruh Disiplin Kerja dan Pelatihan Terhadap Kinerja Karyawan di PT BPR Sejahtera BATAM. JMBI UNSRAT (Jurnal Ilmiah Manajemen Bisnis dan Inovasi Universitas Sam Ratulangi)., 7(1).

Hasibuan, M. S.P. (2016). Manajemen Sumber Daya Manusia. Edisi. Revisi. Jakarta: Penerbit PT Bumi Aksara.

Kristianti, L. S., Affandi, A., Nurjaya, N., Sunarsi, D., \& Rozi, A. (2021). Pengaruh Motivasi Dan Disiplin Kerja Terhadap Kinerja Pegawai Pada Dinas Pariwisata Purwakarta. Jurnal Ilmiah PERKUSI, 1(1), 101-109.

Mangkunegara, A. P. (2016). Manajemen Sumber Daya Manusia Perusahaan. Bandung : PT. Remaja Rosdakarya.

Nurjaya, N., Affandi, A., Ilham, D., Jasmani, J., \& Sunarsi, D. (2021). Pengaruh Kompetensi Sumber Daya Manusia Dan Kemampuan Pemanfaatan Teknologi Terhadap Kinerja Aparatur Desa Pada Kantor Kepala Desa Di Kabupaten Gunungkidul, Yogyakarta. JENIUS (Jurnal Ilmiah Manajemen Sumber Daya Manusia), 4(3), 332-346.

Paramarta, V., Dewi, R. R. V. K., Rahmanita, F., Hidayati, S., \& Sunarsi, D. (2021). Halal Tourism in Indonesia: Regional Regulation and Indonesian Ulama Council Perspective. International Journal of Criminology and Sociology, 10, 497-505.

Rahayu, R. P., \& Ramadhani, R. A. (2018). Pengaruh Pelatihan Kerja Terhadap Kinerja Karyawan Hotel Camplong di Kabupaten Sampang. JURNAL MAKRO MANAJEMEN, 2(2), 131149.

Siskawati, N. (2017). Pengaruh Disiplin Kerja Terhadap Kinerja Karyawan Pada Hotel di Kabupaten Indragiri Hilir. JURNAL ANALISIS MANAJEMEN, 3(1), 89-97. 
Sugiyono. (2017). Metode Penelitian Kuantitatif, Kualitatif, dan RED. Bandung: Alfabeta.

Sulastiyono, A. 2011. Manajemen Penyelenggaraan Hotel seri Manajemen Usaha Jasa Sarana Pariwisata dan Akomodasi. Bandung: Alfabeta.

Sutrisno, E. (2016). Manajemen Sumber Daya Manusia. Jakarta: Kencana Prenada. Media Group.
Tambunan, S. M. (2021). Pengaruh Pelatihan Kerja Terhadap Kinerja Karyawan Pada Akademi Pariwista Medan Hotel School Medan. Jurnal Akuntansi, Manajemen dan Ilmu Ekonomi (Jasmien), 1(02), 55-62.

Widodo, E. S. (2015). Manajemen Pengembangan Sumber Daya Manusia. Yogyakarta: Pustaka Pelajar. 